\title{
Vulvar Squamous Cell Papilloma
}

National Cancer Institute

\section{Source}

National Cancer Institute. Vulvar Squamous Cell Papilloma. NCI Thesaurus. Code C6376.

A benign papillary neoplasm that arises from the vulva and is characterized by the

presence of a delicate fibrovascular stalk lined by squamous epithelium. There is no evidence of epithelial atypia. 